\title{
The application of linear programming to a coal-mining problem: A case study
}

\author{
W.G. Klerck \\ School of Business Leadership, University of South Africa, Pretoria
}

\author{
G.M.S. Tumer \\ Consulting engineer
}

This article describes the application of linear programming to a problem faced by a small coal-mining company. The company owns two operating collieries, one supplies the general inland trade market while the other supplies a power station under a 30-year-tied contract. The company was awarded an export allocation for a 30-year period and as a result was trying to establish how to supply the coal for the various markets. Only the colliery that supplied the power station had sufficient reserves to base an export contract on. It was underlain by two economically recoverable seams of coal. The quality of the coal reserves is, however, low compared to international standards and is therefore unacceptable in its raw state. It is, however, possible to upgrade the coal by washing it. The grade of the final product (float) can be adjusted by altering the density of washing. However the yield, as a percentage of the raw coal feed, falls off rapidly as the grade is increased. Furthermore the sinks can likewise be upgraded by washing. The company wondered how they should optimize the flowsheet. How much coal should they mine from each of the two seams, how much from each source should go to the power station, how much should they produce for export, how should the upgrading be done, and to what extent. A linear programming model was formulated to solve the problem facing the company.

S. Afr. J. Bus. Mgmt. 1985, 16: $46-48$

Hierdie artikel beskryf die gebruik van lineẽre programmering om 'n spesifieke probleem van 'n klein maatskappy in die steen. koolbedryf op te los. Die maatskappy besit twee steenkoolmyne; een bedien die binnelandse mark terwyl die ander een ' $n$ kragstasie van steenkool voorsien volgens 'n 30-jaar-kontrak. ' $n$ Uitvoerkontrak vir 'n periode van 30 jaar is aan die maatskappy toegestaan en as gevolg hiervan moes die maatskappy vasstel op welke wyse die onderskeie markte voorsien moes word. Slegs die steenkoolmyn wat die kragstasie bedien het, het genoeg steenkoolreserwes gehad om aan die uitvoerkontrak te voldoen. Dié myn het twee ekonomiesontginbare steenkoollae gehad. Die kwaliteit van die steenkoolreserwes is egter laag in vergelyking met internasionale standaarde en die steenkool moet gevolglik verder verwerk word. Die verwerking geskied deur die ontginde steenkool te was en sodoende die kwaliteit te verhoog. Die kwaliteit van die finale produk kan verander word deur die digtheid van die wassery te verstel. Die opbrengs, uitgedruk as 'n persentasie van die inset, verminder vinnig as die graad verhoog word. Die afvoer (afval) kan ook opgegradeer word deur dit te was. Die maatskappy wou vasstel hoeveel steenkool van elke steenkoollaag gemyn moet word, hoeveel van elke laag na die kragstasie en hoeveel steenkool van elke laag na die uitvoermark moet gaan. Die maatskappy wou ook vasstel wat die omvang van die opgradering moes wees. ' $n$ Lineêre programmeringsmodel is gebruik om hierdie probleme van die maatskappy op te los.

S.-Afr. Tydskr. Bedryfsl. 1985, 16: $46-48$

\section{W.G. Klerck*}

School of Business Leadership, University of South Africa, P.O. Box 392, Pretoria, 0001 Republic of South Africa

G.M.S. Turnet

Consulting engineer, Pretoria

*To whom correspondence should be addressed

\section{Introduction}

This article describes a problem faced by a small coal-mining company, situated in the eastern Transvaal, South Africa. The company owns two operating collieries. The first has a present capacity of 1 million tons per annum and supplies the general inland trade market. The second colliery supplies 3,6 million tons per annum for power generation under a 30-year-tied contract.

The company was recently awarded an export allocation of at most 2 million tons per annum for a 30-year period. As a result the company was trying to determine what the most efficient method would be to supply the coal for the various markets.

\section{Background to the study}

Both of the company's collieries are underlain by two economically recoverable coal-seams, the No. 2 seam and the No. 4 seam. The No. 5 seam, which has metallurgical properties suitable for the steel industry is not present while the No. 1 and No. 3 seams are too thin to be economically recoverable.

The colliery that supplies the inland trade market has limited reserves and has been ruled out by the company as a proposition on which to base an export colliery.

The colliery that supplies the power station has substantial reserves, in excess of what is required for the power station. The power station supply contract still has 30 years to run, the same period as the proposed export project. Information on reserves and rate of exploitation were obtained and are shown in Table 1.

In addition to these reserves the company has access to a mini-pit proposition. This could, if necessary, supply an additional 0,4 million tons per annum of the No. 4 seam for the duration of the project.

Table 1 Reserves and rate of exploitation

\begin{tabular}{lcc}
\hline & No. 2 seam & No. 4 seam \\
\hline $\begin{array}{l}\text { Remaining recoverable } \\
\text { reserve (million tons) }\end{array}$ & 90 & 99 \\
$\begin{array}{l}\text { Required life (years) } \\
\begin{array}{l}\text { Maximum rate of exploi- } \\
\text { tation/year (million tons) }\end{array}\end{array}$ & 30 & 30 \\
\hline
\end{tabular}

\section{Quality of South African coal}

South African coal reserves are generally of low quality by international standards and as such are unacceptable for 
export in their raw state. In this particular case the quality of the No. 2 seam is $25,5 \mathrm{MJ} / \mathrm{Kg}$ and that of the No. 4 seam $22,0 \mathrm{MJ} / \mathrm{Kg}$, while the minimum international-acceptable quality is $27 \mathrm{MJ} / \mathrm{Kg}$. (MJ/ $\mathrm{Kg}$ or megajoules per kilogram is a measure of the heat content or calorific value of the coal. The higher the heat content the more acceptable the coal.)

However, it is possible to upgrade the coal by washing. The raw coal is crushed and then fed into a vessel containing a heavy liquid medium. This separates the coal into two streams, with part of the coal floating and part sinking. The coal particles that float have a higher calorific value than the raw-coal feed, while the particles that sink are of a lower grade. The grade of the floats can be adjusted by altering the density of washing. However the yield, as a percentage of the raw-coal feed, rapidly falls off as the calorific value is raised, and the process becomes uneconomical.

An analysis was done of the washing characteristics of the company's coal. The results showed a very poor yield for the No. 4 seam and confirmed that it was not a proposition to upgrade this yield to export-quality coal. The No. 2 seam in contrast showed good washing characteristics. The No. 2 seam was tested at two different densities, to produce a $27 \mathrm{MJ} / \mathrm{Kg}$ and a $28 \mathrm{MJ} / \mathrm{Kg}$ float product (Table 2). The company doubted the economics of the $28 \mathrm{MJ} / \mathrm{Kg}$ product because of low yield.

Table 2 Yield for No. 2 seam

\begin{tabular}{lcc}
\hline & Density 1 & Density 2 \\
\hline Product quality, MJ/Kg & 27 & 28 \\
Product yield (floats), \% & 79 & 68 \\
Sinks, \%0 & 21 & 32 \\
Sinks quality, MJ/Kg & 19,5 & 22,3 \\
\hline
\end{tabular}

In the same way that raw coal can be washed, the sinks can be upgraded by washing at a higher density in a secondstage process, to form a middlings product. The analysis of the washing characteristics of the second stage is showed in Table 3.

The quality of the discards from the second stage would not be acceptable for use and would have to be dumped.

The washing plant has a first-stage feed capacity of 2,8 million tons per annum with a second-stage capacity of 1,1 million tons per annum input.

Table 3 Analysis of second-stage washing

\begin{tabular}{lcc} 
& Density 1 & Density 2 \\
\hline Feed quality, MJ/Kg & 19,5 & 22,3 \\
Middlings yield, \% & 56 & 75 \\
Middlings quality, MJ/Kg & 23,9 & 25,1 \\
Discard, \%0 & 44 & 25 \\
Discard quality, MJ/Kg & 12 & 12 \\
\hline
\end{tabular}

\section{The power-station contract}

When the company originally tendered for the power-station supply it planned to mine the No. 2 seam and the No. 4 seam for this purpose and blend them together. (Coals of different calorify. values can be blended linearly.) The company had tendered for a minimum calorific value of $23 \mathrm{MJ} / \mathrm{Kg}$ for the life of the station. The power station had accordingly been designed for this minimum and the company was contractually committed to supply this quality. Any deterioration would severely affect power-station efficiency and output and could not be contemplated.

\section{Production costs and sales revenue}

The No. 4 seam is not as hard but thicker than the No. 2 seam and costs R5,30/ton to mine compared to R7,50/ton for the latter. The mini-pit mining costs had been calculated at $\mathrm{R} 9,30 /$ ton, including overland transport.

The cost of operating the washing plant was estimated at $\mathrm{R} 1,40 /$ ton of feed to the plant with second-stage costs at $\mathrm{R} 0,80 /$ ton input.

On the revenue side the contractual price for feed to the power station was R9,90/ton.

Export coal could be sold for R40/ton FOB for the 27 $\mathrm{MJ} / \mathrm{Kg}$ product. After allowing for railage, port, and handling charges of R14,40/ton, this left the company with an income of $\mathrm{R} 25,60 /$ ton. Similarly, for a $28 \mathrm{MJ} / \mathrm{Kg}$ product the income was calculated at $\mathrm{R} 27,70 /$ ton.

\section{Issues facing the company}

Although the No. 4 seam and mini-pit were only suitable for power-station feed, the No. 2 seam which had traditionally been sent to the power station to make up the required calorific value, could now be washed at either of two densities to produce a $27 \mathrm{MJ} / \mathrm{Kg}$ and/or $28 \mathrm{MJ} / \mathrm{Kg}$ for export, as well as being bypassed to the power station as before. The sinks from either of these operations could be sent to the power station or alternatively could be washed in the second stage to upgrade the quality, with the middlings routed to the power station.

The company wondered how they should go about optimizing the flow-sheet. How much coal should they mine from each of the No. 2 seam, No. 4 seam, and mini-pit? How much from each source would go directly to the power station? How much should they produce for export and what quality should be produced? To what extent should they use the second-stage washing process, considering its low yield?

Reserves did not appear to be a constraint with a mining capacity of 6,7 million tons per annum. Neither did the capacity of the mine's shaft of 5,8 million tons per annum appear to be a constraint. But would the washing plant be big enough?

\section{The model}

The problem was formulated as a linear programming model. To formulate the model a flow chart of the 'mining operations' was drawn. This is shown in Figure 1.

\section{Decision variables}

The decision variables appear on the flow chart and are:

$S_{1}$ - Tons mined per annum from the mini-pit.

$S_{2}$ - Tons mined per annum from No. 4 seam.

$S_{3}$ - Tons mined per annum from No. 2 seam.

$W_{1}$ - No. 2 seam tons per annum to power station.

$W_{2}-$ No. 2 seam tons per annum to Washing Stage 1, Density 1 .

$W_{3}$ - No. 2 seam tons per annum to Washing Stage 1, Density 2.

$X_{1}$ - Tons of $27 \mathrm{MJ} / \mathrm{Kg}$ quality exported per year.

$X_{2}$ - Tons of $28 \mathrm{MJ} / \mathrm{Kg}$ quality exported per year.

$Y_{1}$ - Tons sinks per annum from Washing Stage 1, Density 1 to Power Station. 


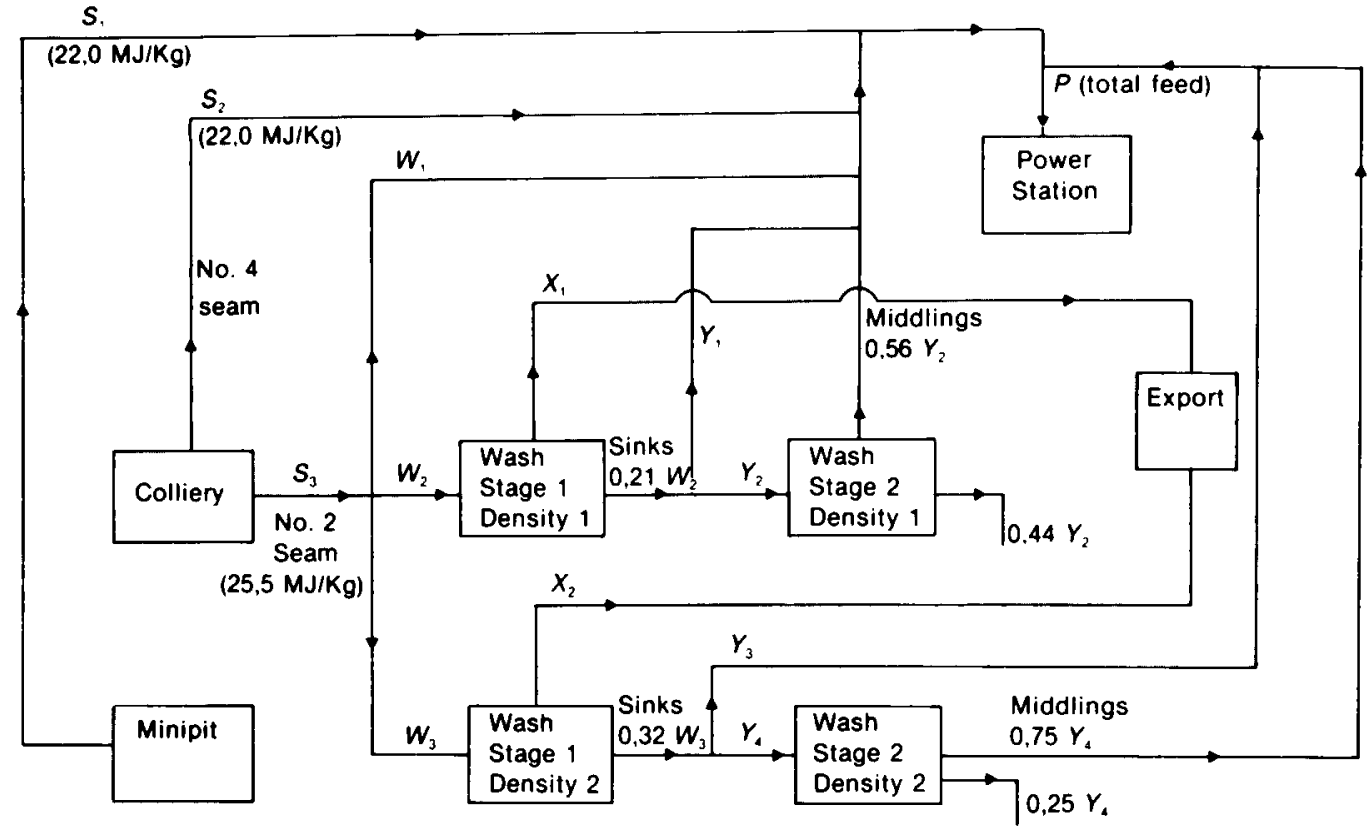

Figure 1 Flow diagram of mining operations.

$Y_{2}$ - Tons sinks per annum from Washing Stage 1, Density 1 to Washing Stage 2, Density 1.

$Y_{3}$ - Tons sinks per annum from Washing Stage 1, Density 2 to Power Station.

$Y_{4}$ - Tons sinks per annum from Washing Stage 1, Density 2 to Washing Stage 2, Density 2.

$P$ - Total feed to the power station.

The constraints for this problem refer to the maximum rate of exploitation, shaft capacity, rail contract, export contract, washing-plant capacity, power-station supply, and the grade constraint for the power-station supply. These constraints as well as the objective function are as follows:

\section{Material balance}

$S_{3}-W_{1}-W_{2}-W_{3}=0$

$X_{1}-0,79 W_{2}=0$

$0,21 W_{2}-Y_{1}-Y_{2}=0$

$X_{2}-0,68 W_{3}=0$

$0,32 W_{3}-Y_{3}-Y_{4}=0$

$S_{1}+S_{2}+W_{1}+Y_{1}+0,56 Y_{2}+Y_{3}+0,75 Y_{4}-P=0$

\section{Maximum rate of exploitation}

$S_{1} \leqq 0,4$

$S_{2} \leqq 3,3$

$S_{3} \leqq 3,0$

\section{Shaft capacity}

$S_{2}+S_{3} \leqq 5,8$

Rail contract

$X_{1}+X_{2} \geqq 1,0$

\section{Export contract}

$X_{1}+X_{2} \leqq 2,0$

Washing-plant capacity

$W_{2}+W_{3} \leqq 2,8$

$Y_{2}+Y_{4} \leqq 1,1$

Power-station supply

$P=\mathbf{3 , 6}$
Grade constraint power station

$\frac{\text { Total MJ produced }}{\text { Total tons produced }} \geqq 23,0$

i.e. $22,0 S_{1}+22,0 S_{2}+25,5 W_{1}+19,5 Y_{1}+22,3 Y_{3}$ $+23,9\left(0,56 Y_{2}\right)+25,1\left(0,75 Y_{4}\right) \geqq 23(3,6)$

\section{Objective function}

Maximize $-9,3 S_{1}-5,3 S_{2}-7,5 S_{3}-1,4 W_{2}-1,4 W_{3}$ $-0,8 Y_{2}-0,8 Y_{4}+9,9 P+25,6 X_{1}+27,7 X_{2}$

\section{Results}

The solution obtained from the model indicates that the company should mine 3 million tons per annum from the No. 2 seam and 2,5 million tons from the No. 4 seam per annum. Nothing should be mined from the mini-pit. Of the 3 million tons mined from the No. 2 seam approximately 0,5 million tons should be sent directly to the power station and 2,5 million tons to the washing plant where Density- 2 washing will be applied. Approximately 1,7 million tons of this 2,5 million tons will be exported, the quality being $28 \mathrm{MJ} / \mathrm{Kg}$. During Stage 2 of the washing plan 0,8 tons will be processed. Of the 0,8 tons approximately 0,6 tons will be routed to the power station. The average quality of the coal supplied to the power station is $23 \mathrm{MJ} / \mathrm{Kg}$. The total yearly income received by following this solution is $\mathrm{R} 42,9$ million.

With the exception of the power station grade constraint and the No. 2 seam rate of exploitation constraint all the constraints have slack; indicating that the capacities of the shaft, working plant, etc. are sufficient.

According to the solution the company should supply 1,7 million of the 2 million tons export contract. The reason being that the No. 2 seam maximum rate of exploitation constraint is binding and the export contract is only supplied from this seam. If the company wants to increase the tonnage on the export contract it will have to consider its policy on the maximum rate of exploitation.

\section{Conclusion}

This case study described the application of linear programming to a small coal-mining problem and illustrated how linear programming can assist the managemerk of the company to solve a reasonable complex problem. 